\title{
The Nuclear Microprobe a Challenging Tool in Plant Sciences
}

\author{
J. Mesjasz-PrzybyŁowicz* \\ Materials Research Group, National Accelerator Centre \\ P.O. Box 72, Faure 7131, South Africa
}

The nuclear microprobe is a microanalytical tool capable of quantitative studies of elemental distribution at the ppm level with a spatial resolution of the order of $1 \mu \mathrm{m}$. This sensitivity is adequate for most elements of interest, and the spatial resolution is acceptable for studies of elemental distribution in organs, tissues, and cells. The main techniques used in plant science are particle induced X-ray emission using protons, proton backscattering, scanning transmission ion microscopy, and particle induced gamma-ray emission. Specimen preparation is the most difficult part of analysis, and only cryotechniques are recommended presently for all types of microanalytical studies.

PACS numbers: $89.60 .-\mathrm{k}, 41.75 .-\mathrm{i}, 07.78 .+\mathrm{s}$

\section{Introduction}

The nuclear microprobe is one of the microanalytical tools, which allow investigating elemental concentrations and distribution at ppm level. It has been successfully used in basic and applied plant sciences for more than 20 years [1-4]. Microanalysis using nuclear microprobe is now a well-established technique, although perhaps not as exploited in botany as in other fields like geology and materials science.

Potential applications are in plant physiology - in studies of the role played by particular elements in fundamental physiological processes; in plant nutrition; interactions between elements including elemental deficiency and toxicity; information on transport, sequestration, and functions of minor and trace elements. Microanalysis could provide a link between anatomical studies and plant physiology and it has practical implications in applied sciences — agriculture and horticulture.

*e-mail: mesjasz@srvnac3.nac.ac.za, mesjasz@nac.ac.za 
Eco-physiological studies is another area where micro-particle induced X-ray emission (micro-PIXE) is successfully used, documenting responses of plant tissues to environmental stress, particularly caused by heavy metals occurring naturally and introduced by pollution. Knowledge of localization and quantification of toxic elements in a plant indicates possible pathways of transport and mechanisms of detoxification and can assist in understanding plant adaptation to hostile environment.

Since last botanical review [4] more results have been published covering broad range of applications e.g. plant response to environmental stress caused by unbalanced nutrient composition in phytoplankton [5], salinity [6-11] and heavy metals (in lichens [12, 13], mycorrhizas [14-18], tree rings [19], seeds [20-24], seagrasses [25], and plants hyperaccumulating heavy metals [26-28]). The physiological studies were conducted on Si [29], Ca [30], Al [31], and Fe [32, 33].

Knowledge about advantages and restrictions of the ion-beam techniques with information where they could be successfully applied will allow increasing number of applications.

\section{Description of the facility}

Nuclear microprobe uses analytical signals generated in a specimen by focused ion beams. In most biological applications proton beams of energies $2-4 \mathrm{MeV}$ are used with a spatial resolution of the order of $1 \mu \mathrm{m}$. Generation of beams of such energies requires an accelerator, typically single ended or tandem Van de Graaff accelerator. The mostly used technique is PIXE, utilizing characteristic $\mathrm{X}$-ray radiation for elemental microanalysis. X-rays are typically detected in energy dispersion mode (EDS) and the range covered in one run can theoretically extend from $\mathrm{Na}$ to $\mathrm{U}$. The limit on the low atomic number side is related to the absorption of characteristic X-ray radiation in the window of an Si( $\mathrm{Li}$ ) or HPGe detector used. Complementary techniques such as proton backscattering (BS) and scanning transmission ion microscopy (STIM) in the on-axis or off-axis mode of operation provide additional information on specimen matrix composition and its areal density, necessary for quantitative elemental analysis. Measurements of selected light elements (F, Li, B) below the PIXE range can be performed using particle induced gamma-ray emission (PIGE).

The main strengths of nuclear microprobe lie in its sensitivity, multielemental character of analysis, and easy quantification. The detection limits can be down to ppm (part-per-million) level and in a biological matrix, composed of light elements, are usually lower than in other types of specimens. Simultaneous quantitative studies of major, minor, and trace elements are possible. Very easy beam steering makes the scanning nuclear microprobe an instrument with unique capabilities for two-dimensional elemental mapping of minor and trace elements. High scanning speeds are recommended to minimize specimen damage (mostly due 
to heat deposited by beam). Easy construction of elemental maps at sensitivity levels matching concentrations of trace elements in plant parts presents unique research opportunities. However, not every existing facility has equal capabilities of analysis due to various data acquisition systems used. True elemental imaging with elemental maps which are inherently resolved of elemental overlaps, without background influence and quantitative $[34,35]$, is particularly useful.

\section{Specimen preparation}

Elemental analysis and localization requires that the material under consideration is maintained as close as possible to its functional state (in vivo), and this applies to all microanalytical techniques.

Proper specimen sampling and further preparation are the crucial part of microanalysis and, according to present knowledge, only cryotechniques are recommended. The description of the cryotechniques can be found elsewhere [36-38].

It is important to stress purity at all stages of sampling and preparation because of high sensitivity of PIXE technique to detect elements at ppm levels. It is also crucial to minimize time between sampling and cryofixation. The analyses using nuclear microprobe are done in vacuum of the order of $10^{-5} \mathrm{mbar}$ (except special cases of using external ion beam). It means that water has to be removed and the specimens have to be immobilized in the defined functional state. The typical scheme of different ways of specimen preparation is shown in Fig. 1.

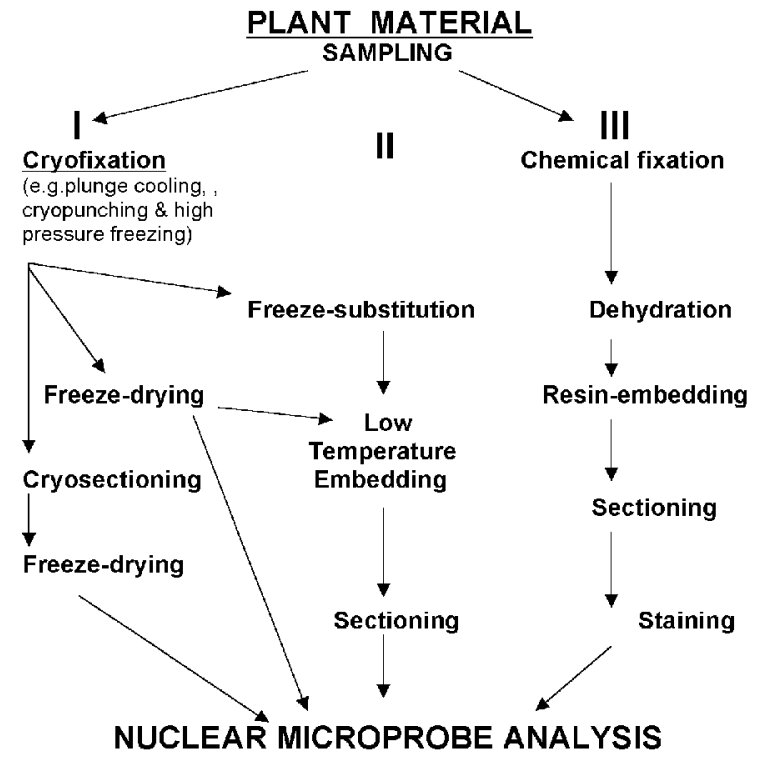

Fig. 1. Scheme of different types of preparation protocols for nuclear microprobe analysis. 
The most recommended is path I using different cryotechnique protocols. The best, but also most difficult part is cryosectioning, due to heterogeneity of plant non-meristematic tissues (virtually structureless vacuoles and strong plant cell wall) in comparison with animal and human tissues. Only two research groups achieved success in this field so far [39-43].

Path III presents well known conventional chemical preparation for light and electron microscopy. These invasive procedures are generally based on fixations in chemical solutions, staining, dehydration, and embedding in plastic resin (in ambient and higher temperature) for longer time. It is evident that some elements are added and some are washed out or redistributed (e.g. [17]). Losses and addition of elements even when they are not elements of interest in particular studies (e.g. light, matrix forming elements) could indirectly influence the concentrations.

Path II is a compromise between procedures I and III and should be applied with caution.

The other possibility is when external beam is used. In this case large specimens can be measured and in practice no special preparation is required. However, this option is seldom used as the resolution of analysis drastically deteriorates and is of the order of few tens of $\mu \mathrm{m}$.

The specimens are usually mounted on a very thin plastic foil (e.g. Formvar, Pioloform, nylon) free of elemental impurities and carbon coated to prevent charge build-up during analysis. Sometimes a specimen is mounted between two layers of foil.

It is important to minimize time when dry specimens are exposed to humidity in air and they should be stored in desiccator prior to analysis.

\section{Examples of applications}

Three examples of applications - from plant physiology, plant response to pathogen and plant response to polluted environment - are presented. In every case only elemental maps are shown, as the complete information cannot be obtained using only points or even linear traverses. Analyses were performed using the nuclear microprobe at the National Accelerator Centre, Faure, South Africa. Quantitative elemental maps were obtained using $3 \mathrm{MeV}$ protons and dynamic analysis method of imaging. All specimens were cryofixed, freeze-dried, mounted on Formvar films and carbon coated. More detailed description of analytical procedure can be found elsewhere [44].

\subsection{Mechanism of elemental uptake}

Zinc is one of essential micronutrients as a component of number of enzymes. Mechanism of zinc uptake is still not well understood and it is not determined whether it is a passive or active process. Young roots cross-section of Phaseolus vulgaris L. (Fabaceae) were investigated [45]. The results clearly indicate high 


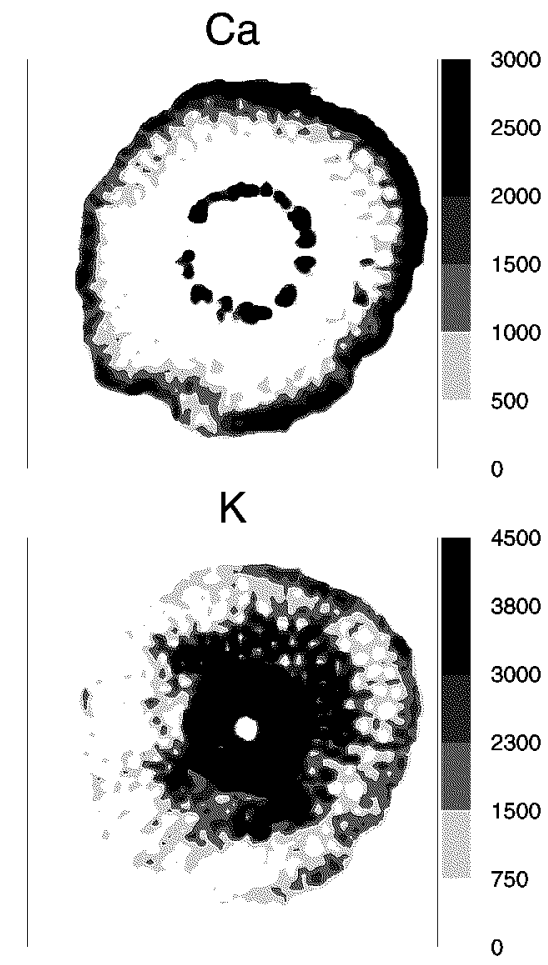

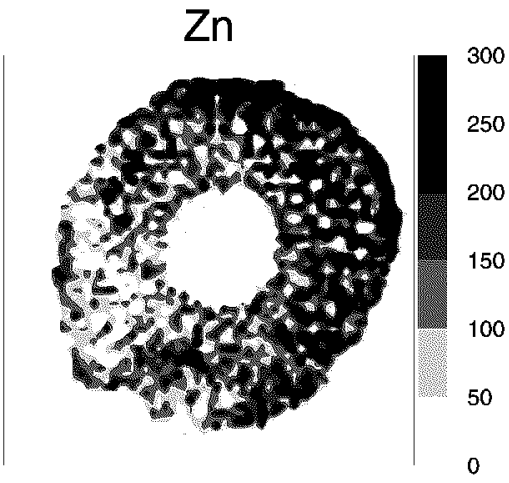

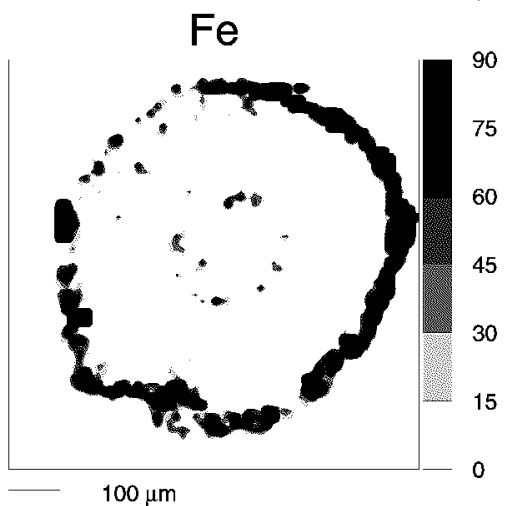

Fig. 2. Quantitative elemental maps showing distribution of $\mathrm{Zn}, \mathrm{Fe}, \mathrm{Ca}$, and $\mathrm{K}$ in the root cross-section of Phaseolus vulgaris L. (Fabaceae). Concentrations in $\mathrm{mg} \mathrm{kg}^{-1} \mathrm{dry}$ mass. Maximum concentration should be treated as $\geq$ to those indicated by the scale.

concentrations of zinc in the cortex, while low concentrations are present inside the endodermis (Fig. 2). Zinc is not transported to the xylem and this might indicate a passive absorption mechanism. The maps of elemental distribution show high concentrations of zinc in the cell walls, thus indicating an adsorption phase rather than uptake into cytoplasm. Comparison of the localization of zinc with more mobile elements showed that potassium was mainly inside the endodermis which might be an evidence for an active transport across the endodermis into the conducting tissue of xylem. In contrast, zinc transport appears to be a passive process.

\subsection{Plant resistance to pathogen infection}

Disease resistance in plants is often expressed as the hypersensitive response (HR), a rapid, localized plant cell death that is associated with the restriction of pathogen growth.

A resistant genotype of wild plant (Lagenaria sphaerica (Sonder) Naudin, Syn. Lagenaria mascarena Naudin) from Cucurbitaceae has been inoculated by a 
foliar fungal pathogen (Sphaerotheca fuliginea (Schlecht. ex Fries) Poll) [46, 47].

The accumulation of $\mathrm{Ni}, \mathrm{Cu}, \mathrm{Zn}, \mathrm{Mn}, \mathrm{Fe}, \mathrm{Ca}, \mathrm{Ti}, \mathrm{As}, \mathrm{Sr}$ as well as drastic depletion of macronutrient levels $(\mathrm{P}, \mathrm{S}, \mathrm{K})$ occurred in invaded region during the first four days. Six days after inoculation, necrotic cells with high level of Mn (Fig. 3) surrounded lesions. Si deposition in concentrations up to 23 wt.\% occurred after accumulation of most metals in fully necrotic lesions. Changes of elemental distribution in time suggest that metal accumulation to phytotoxic levels may contribute to death of infected cells, and that subsequent Si accumulation provides an impermeable, non-toxic barrier protecting the surrounding uninfected tissue. The enrichment of two selected, potentially phytotoxic, elements $(\mathrm{Mn}, \mathrm{Ni})$ as well as macronutrient $(\mathrm{Ca})$ and the depletion of macronutrient $(\mathrm{K})$ is shown in Fig. 3 .

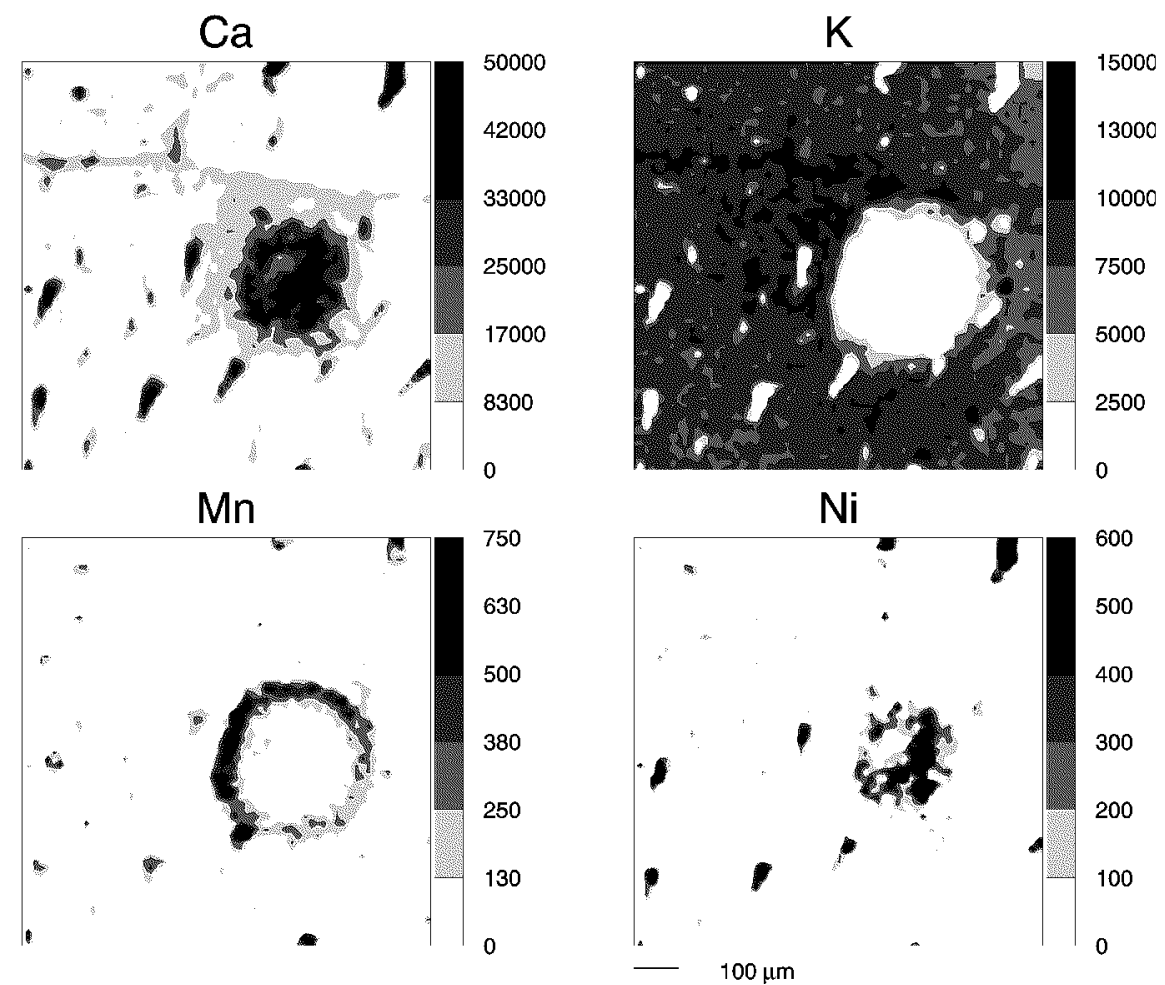

Fig. 3. Quantitative elemental maps of $\mathrm{Ca}, \mathrm{Ni}, \mathrm{Mn}$, and $\mathrm{K}$ in 6 day lesion caused by Sphaerotheca fuliginea (Schlecht. ex Fries) Poll. on resistant Lagenaria sphaerica (Lagenaria sphaerica (Sonder) Naudin (Cucurbitaceae)) leaf. Scale of intensity in $\mathrm{mg} \mathrm{kg}^{-1}$ dry mass. Maximum concentration should be treated as $\geq$ to those indicated by the scale. 


\subsection{Plant response to polluted environment}

Biscutella laevigata L. (Brassicaceae), a rare perennial metallophyte plant species known mainly from Central and Southern Europe, has a very restricted distribution in Poland. These results focus on one known Polish lowland location of B. laevigata on calamine dumps near Olkusz, Upper Silesia and they are part of broader studies to understand mechanisms of plant adaptation to a hostile environment, rich in heavy metals [22-24]. Quantitative elemental maps showed that seed tissue was defined by specific elemental allocation patterns (Fig. 4). The highest concentration of $\mathrm{Zn}$ and other heavy metals was found in the endosperm. Most probably endosperm works as a barrier actively controlling elemental uptake and preventing access of toxic amounts to embryonic parts. Within embryonic tissue, the highest amount of $\mathrm{Zn}$ was found in the radicle. These results show that plants strictly and actively select elements and their amounts taken up by different tissues. This mechanism is probably responsible for their survival.

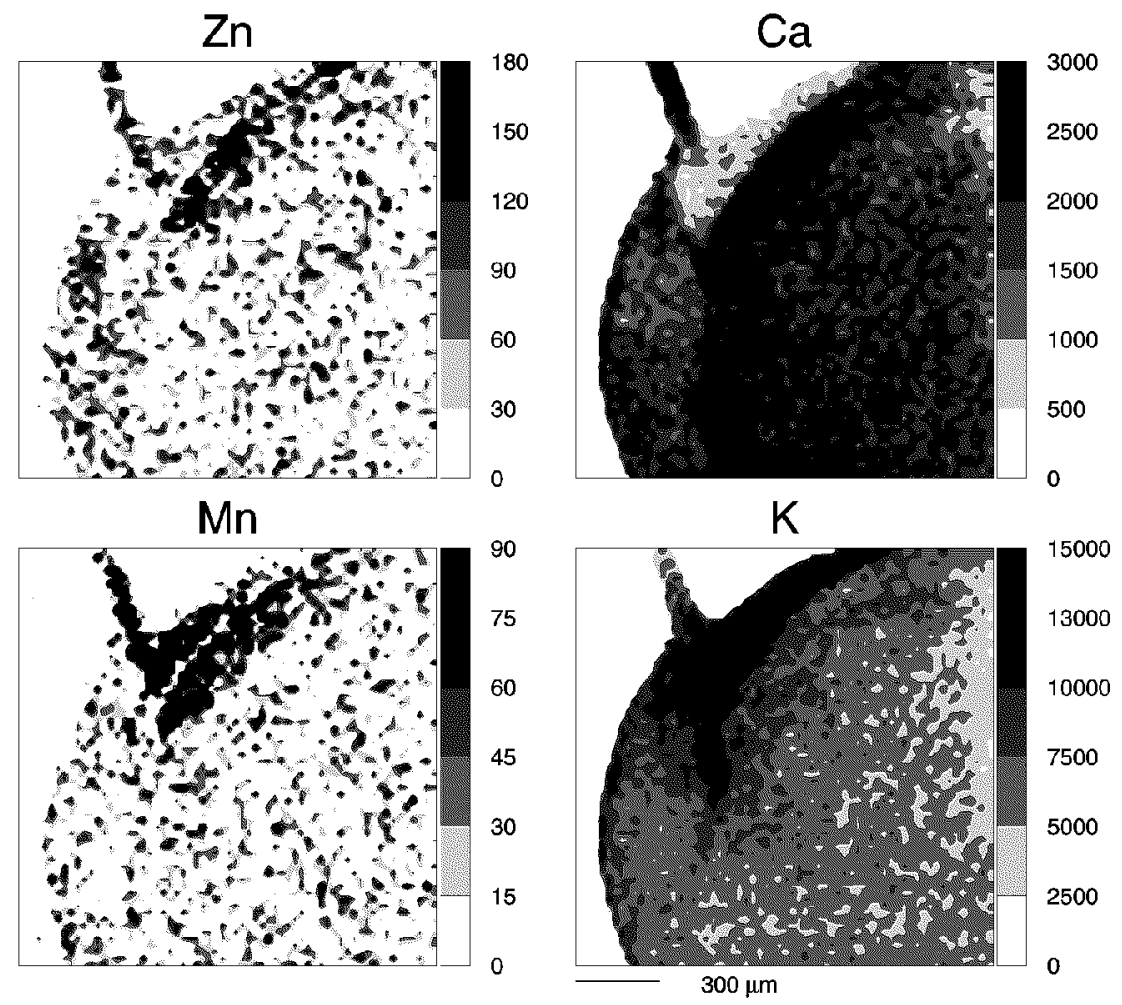

Fig. 4. Quantitative elemental maps showing distribution of $\mathrm{Zn}, \mathrm{Mn}, \mathrm{Ca}$, and $\mathrm{K}$ in seed part of Biscutella laevigata L. (Brassicaceae), a rare metallophyte plant from zinc dump in Olkusz area (Southern Poland). Concentrations in $\mathrm{mg} \mathrm{kg}^{-1}$ dry mass. Maximum concentration should be treated as $\geq$ to those indicated by the scale. 


\section{Conclusions and remarks}

Recommended approach to perform analysis using a nuclear microprobe is to start with bulk technique analysis and sometimes with less sensitive electron microprobe to avoid addressing problems which could be solved by other, cheaper and more easily accessible techniques. Technically this is not an easy instrument to operate by a person without experience. Therefore applications in plant sciences are an example of multidisciplinary research where close collaboration between plant scientists and physicists is crucial and it is a key to success.

\section{References}

[1] G.J.F. Legge, C.D. McKenzie, A.P. Mazzolini, J. Microsc. 117, 185 (1979).

[2] F. Bosch, A. El Goresy, W. Herth, W. Martin, R. Nobiling, B. Povh, H.-D. Reiss, K. Traxel, Nucl. Sci. Appl. 1, 35 (1980).

[3] G.J.F. Legge, A.P. Mazzolini, Nucl. Instrum. Methods 168, 563 (1980).

[4] W.J. Przybylowicz, J. Mesjasz-Przybylowicz, V.M. Prozesky, C.A. Pineda, Nucl. Instrum. Methods Phys. Res. B 130, 335 (1997).

[5] J. Pallon, M. Elfman, P. Kristiansson, K. Malmqvist, E. Granéli, A. Sellborn, C. Karlsson, Nucl. Instrum. Methods Phys. Res. B 158, 312 (1999).

[6] W.J. Przybylowicz, C.A. Pineda, A.D. Barnabas, J. Mesjasz-Przybylowicz, Nucl. Instrum. Methods Phys. Res. B 150, 282 (1999).

[7] A.D. Barnabas, R. Jagels, W.J. Przybylowicz, J. Mesjasz-Przybylowicz, in: Microscopy and Microanalysis, Eds. G.W. Bailey, K.B. Alexander, W.G. Jerome, M.G. Bond, J.J. McCarthy, Vol. 4, Springer, New York 1998, p. 1174.

[8] A.D. Barnabas, R. Jagels, W.J. Przybylowicz, J. Mesjasz-Przybylowicz, in: Proc. 14th Int. Congress on Electron Microscopy, Cancun (Mexico) 1998, Eds. H.A. Calderon Benavides, M.J. Yacaman, Instituto de Fisica, UNAM and ININ, Mexico 1998, p. 45.

[9] A.D. Barnabas, P. Bunsi, Y. Naidoo, W.J. Przybylowicz, J. Mesjasz-Przybylowicz, in: Microscopy and Microanalysis, Eds. G.W. Bailey, W.G. Jerome, S. McKernan, J.F. Mansfield, R.L. Price, Vol. 5, Suppl. 2, Springer, New York 1999, p. 1256.

[10] A.D. Barnabas, P. Bunsi, Y. Naidoo, J. Mesjasz-Przybylowicz, W.J. Przybylowicz, Proc. Microsc. Soc. South. Afr. 29, 48 (1999).

[11] A.D. Barnabas, R. Jimmy, K. Govender, W.J. Przybylowicz, J. Mesjasz-Przybylowicz, in: Proc. 12th European Congress on Electron Microscopy (EUREM2000), Brno (Czech Republic) 2000, Eds. P. Ciampor, L. Frank, Vol. 1, Biological Sciences, Czechoslovak Society for Electron Microscopy, Brno 2000, p. 147.

[12] B.M. Clark, N.F. Mangelson, L.L. St. Clair, J.S. Gardner, L.S. Cooper, L.B. Rees, P.G. Grant, G.S. Bench, Nucl. Instrum. Methods Phys. Res. B 150, 248 (1999).

[13] D. Budka, W.J. Przybyłowicz, J. Mesjasz-Przybyłowicz, K. Sawicka-Kapusta, Nucl. Instrum. Methods Phys. Res. B, in press.

[14] I.M. Weiersbye, C.J. Straker, W.J. Przybylowicz, Nucl. Instrum. Methods Phys. Res. B 158, 335 (1999). 
[15] M. Maetz, A. Schüßler, A. Wallianos, K. Traxel, Nucl. Instrum. Methods Phys. Res. B 150, 200 (1999).

[16] J. Mesjasz-Przybylowicz, W.J. Przybylowicz, B. Godzik, K. Turnau, Proc. Microsc. Soc. South. Afr. 28, 64 (1998).

[17] K. Turnau, W.J. Przybylowicz, J. Mesjasz-Przybylowicz, Nucl. Instrum. Methods Phys. Res. B, in press.

[18] A. Jurkiewicz, K. Turnau, J. Mesjasz-Przybyłowicz, W. Przybyłowicz, B. Godzik, Protoplasma, in press.

[19] G. Lövestam, E.-M. Johansson, S.A.E. Johansson, J. Pallon, Ambio 19, 87 (1990).

[20] H.L. Malan, J. Mesjasz-Przybylowicz, W.J. Przybylowicz, J.M. Farrant, Proc. Microsc. Soc. South. Afr. 28, 62 (1998).

[21] H.L. Malan, Ph.D. thesis, Univ. of Cape Town, 1999.

[22] J. Mesjasz-Przybylowicz, K. Grodzinska, W.J. Przybylowicz, B. Godzik, G. Szarek-Lukaszewska, Proc. Microsc. Soc. South. Afr. 28, 61 (1998).

[23] J. Mesjasz-Przybylowicz, K. Grodzinska, W.J. Przybylowicz, B. Godzik, G. Szarek-Lukaszewska, Nucl. Instrum. Methods Phys. Res. B 158, 306 (1999).

[24] J. Mesjasz-Przybylowicz, W.J. Przybylowicz, K. Grodzinska, B. Godzik, G. Szarek-Lukaszewska, Nucl. Instrum. Methods Phys. Res. B 181, 634 (2001).

[25] A.D. Barnabas, W.J. Przybylowicz, J. Mesjasz-Przybylowicz, C.A. Pineda, Nucl. Instrum. Methods Phys. Res. B 158, 323 (1999).

[26] T. Schneider, A. Haag-Kerwer, M. Maetz, M. Niecke, B. Povh, T. Rausch, A. Schüßler, Nucl. Instrum. Methods Phys. Res. B 158, 329 (1999).

[27] J. Mesjasz-Przybylowicz, W.J. Przybylowicz, C.A. Pineda, South African J. Sci., in press.

[28] J. Mesjasz-Przybylowicz, W.J. Przybylowicz, D.B.K. Rama, C.A. Pineda, South African J. Sci., in press.

[29] W.H.O. Ernst, R.D. Vis, F. Piccoli, J. Plant Physiol. 146, 481 (1995).

[30] A.C.J. Timmers, H.-D. Reiss, J. Bohsung, K. Traxel, J.H.N. Schel, Protoplasma 190, 107 (1996).

[31] R.M.S. Schofield, J. Pallon, G. Fiskesjö, G. Karlsson, K.G. Malmqvist, Planta 205, 175 (1998)

[32] T. Schneider, O. Strasser, M. Gierth, W. Przybylowicz, J. Mesjasz-Przybylowicz, C. Churms, A. Schüßler, B. Povh, Int. J. PIXE 9, 353 (1999).

[33] O. Strasser, K. Köhl, V. Römheld, Plant and Soil 210, 179 (1999).

[34] C.G. Ryan, D.N. Jamieson, Nucl. Instrum. Methods Phys. Res. B 77, 203 (1993).

[35] C.G. Ryan, D.N. Jamieson, C.L. Churms, J.V. Pilcher, Nucl. Instrum. Methods Phys. Res. B 104, 157 (1995).

[36] A.W. Robards, U.B. Sleytr, Low Temperature Methods in Biological Electron Microscopy, Elsevier, Amsterdam 1985.

[37] Cryotechniques in Biological Electron Microscopy, Eds. R.A. Steinbrecht, K. Zierold, Springer-Verlag, Berlin 1987.

[38] P. Echlin, Low Temperature Microscopy and Analysis, Plenum Press, New York 1992. 
[39] D.B. Lazof, J.K.G. Goldsmith, T.W. Rufty, C. Suggs, R.W. Linton, J. Microsc. 176, 99 (1994).

[40] D.B. Lazof, J.K.G. Goldsmith, T.W. Rufty, R.W. Linton, Plant Physiol. 112, 1289 (1996).

[41] B. Frey, I. Brunner, P. Walther, C. Scheidegger, K. Zierold, Plant, Cell Environ. 20, 929 (1997).

[42] B. Frey, C. Keller, K. Zierold, R. Schulin, Plant, Cell Environ. 23, 675 (2000).

[43] T. Schneider, A. Haag-Kerwer, M. Maetz, M. Niecke, B. Povh, T. Rausch, A. Schüßler, Nucl. Instrum. Methods Phys. Res. B 158, 329 (1999).

[44] W.J. Przybylowicz, J. Mesjasz-Przybylowicz, C.A. Pineda, C.L. Churms, K.A. Springhorn, V.M. Prozesky, X-ray Spectrometry 28, 237 (1999).

[45] J.A. van As, J.H. Jooste, J. Mesjasz-Przybylowicz, W.J. Przybylowicz, Proc. Electron Microsc. Soc. South. Afr. 25, 34 (1995).

[46] I.M. Weiersbye, C.J. Straker, W.J. Przybylowicz, J. Mesjasz-Przybylowicz, Proc. Electron Microsc. Soc. South. Afr. 26, 66 (1996).

[47] I.M. Weiersbye-Witkowski, W.J. Przybylowicz, C.J. Straker, J. Mesjasz-Przybylowicz, Nucl. Instrum. Methods Phys. Res. B 130, 388 (1997). 